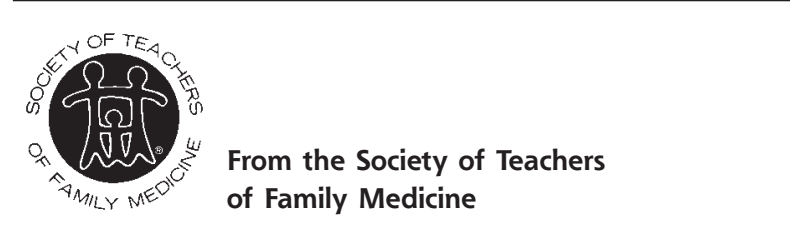

Ann Fam Med 2008;6:567-568. DOI: 10.1370/afm.935.

\section{STFM'S SPECIAL TASK FORCE ON THE FUTURE OF FAMILY MEDICINE: ACCOMPLISHMENTS AND PLANS}

The STFM Board formed its Future of Family Medicine (FFM) Special Task Force in April 2005 to insure that the Society effectively addressed the FFM Strategic Initiative 8 which focused on recruiting and training a culturally diverse workforce. This article updates Annals readers on this task force's activities, accomplishments, and plans in the following 4 focus areas:

- Pipeline programs to address workforce issues

- Competency-based curricula

- Applicant and entering resident academies

- Leadership development.

\section{Pipeline Programs}

The pipeline programs initiative aimed to increase the number of medical school graduates entering family medicine residencies. The members of this component have:

- Created the STFM Group on Pre Medical Pipeline (The STFM Board approved this group on August 3);

- Initiated and continued collaborations with the National Area Health Education (AHECs) organization and published a series of articles in the STFM Messenger;

- Worked with the STFM Board to establish and fund Board and volunteer liaisons to the National AHEC Organization (NAO) through 2009;

- Worked with the STFM Board to considering the liaison role to the $\mathrm{NAO}$ when selecting members at large.

\section{Competency-Based Curricula in the Patient- Centered Medical Home (PCMH)}

The members of the group worked to develop a continuum of teaching and learning resources for predoctoral, residency, and preceptor/faculty development. The learning modules cover 4 important areas. A fifth area, evidence-based medicine, is now being developed by the STFM Group on Evidence-based Medicine and will be released before April 2009. A unit on the electronic health record was initially envisioned, but the great diversity and practical implementation issues surrounding EHRs prevented development of a use- ful module. The following elements of STFM's competency-based curricula are available on the Family Medicine Digital Resource Library (FMDRL):

- Group visits (leader: Julie Schirmer, LCSW) http://www.fmdrl.org/group/index.cfm?event=c. showWikiHome\&wikild=15

- Advanced access (leader: George Valko, MD) http://www.fmdrl.org/group/index.cfm?event=c. showWikiHome\&wikiId $=25$

- Quality improvement (leaders: Peter Carek, MD and Bill Shore, MD) http://www.fmdrl.org/group/index. cfm?event $=$ c.show WikiHome\&wikild $=22$

- The chroic care model (leader: Jeff Susman, MD) http://www.fmdrl.org/group/index.cfm?event=c. showWikiHome\&wikild=21

Each module contains goals, objectives, evaluation materials, checklists, teaching activities and faculty development suggestions. Visit the links above to see what's available to help support local efforts including additional resources such as a summary of initial findings from the TransforMED project, presentations on developing registries and implementing the EHR, and paths to planned care. These modules also illustrate how authors can successfully collaborate online without expensive face-to-face meetings.

\section{The Applicant and Entering Resident (IMG) Academies}

These academies were seen as a way of better preparing international medical graduates (IMGs) to apply to and enter family medicine residency program. Over the past 2 years, STFM staff and a number of STFM members have spent considerable time developing content and materials and marketing the academies. Both academies have been presented by faculty who are STFM members. Of the 2, the Applicant Academy has proven to have the greatest likelihood of attracting enough participants to merit offering it. The content of the Entering Resident Academy (for residents who have matched with family medicine residencies) was well-received, but participants did not enroll in enough numbers for a variety of reasons. While unexpected low numbers of participants resulted in a net loss for STFM, faculty and participating learners expressed great satisfaction with the curriculum. Thus, committee members are considering how the instructional materials can be shared with program directors and residency faculty for presentation to local residents. Faculty members from the Applicant Academy are developing a business plan to make the academy a permanent offering. There was some discussion about offering the Applicant Academy at the annual Resident and Student Conference, but there were logistical barriers that have so far prevented this. 


\section{Leadership Development}

Task force members agree that identifying and developing future leaders in the discipline should be a major priority. Terry Steyer, STFM president-elect, is forming a leadership workgroup consisting of STFM members who will meet face-to-face and by conference call to identify needs of future leaders, plan developmental activities to meet those needs, and specify outcome measures to assess the success of the leadership development activities. The STFM Board voted to support this workgroup with $\$ 7,000$. This workgroup will develop a comprehensive leadership plan with assessment measures and collaborate with the STFM Nominations and Executive Committees to identify, select, and develop future leaders. Other possible ways of developing leaders include ensuring that former/current Pisacano Fellows belong to and participate in STFM activities and monitoring conference proceedings to identify developing leaders.

\section{Dissemination of Task Force Outcomes}

The task force will disseminate its work in multiple ways. One, it will publish summaries of accomplishments in the online STFM Messenger. Two, it will present a seminar on its work at the 2009 STFM Annual Spring Conference. Three, it will prepare a project summary poster that can be viewed near the registration desk at the 2009 STFM Annual Spring Conference. Four, it will post project information and materials on STFM's Family Medicine Digital Resources Library (http://www.fmdrl. org). Fifth, it will submit separate presentation proposals on the 4 priority projects for the 2010 AAMC Annual Meeting. Sixth, it will submit proposals to present project outcomes at AAFP, RPS, and PDW meetings.

STFM Future of Family Medicine Special Task Force Members

Janice Benson, MD Angela Broderick, CAE Stacy Brungardt, CAE Caryl Heaton, DO Charles Mouton, MD William Mygdal, EdD, Chair Jobn Rogers, MD

Terry Steyer, MD Jeff Susman, MD Jim Tysinger, $\mathrm{PbD}$ Ellen Whiting, MEd Deborab Witt, MD Katby Zoppi, PbD

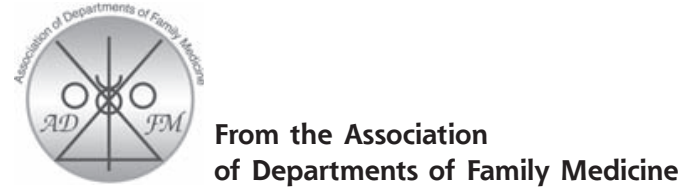

Ann Fam Med 2008;6:568-569. DOI: 10.1370/afm.929.

\section{DEAR MR. PRESIDENT: REFORM HEALTH CARE, AND KEEP IT SIMPLE}

\section{Dear Mr. President}

Congratulations on your election. We, the nation's departments of family medicine, look forward to giving you a hand with health care reform. Compared to other rich nations, we know that our health outcomes fall far short, our health care costs are very high, and access to care is altogether inequitable. Rectifying these problems seems a daunting task, but when attention is paid to the abundant evidence, the solution boils down to 2 simple essentials - universal access to healthcare for all Americans, and much more emphasis on primary care, preventive medicine, and public health.

You may ask: "How will we pay for greater access and for more primary care?" Solid evidence shows that the initial cost for this type of reform is recouped within 2 years and then there are substantial savings. Just ask Senator Richard Burr of North Carolina. He can tell you about his state's great Community Care of North Carolina program. ${ }^{1}$

Like oil companies, we in academic family medicine are concerned about pipelines. For the best health care system, we need to train more family physicians. Ask Senator Edward Kennedy of Massachusetts. His state introduced a program of universal health care coverage in 2006, but it failed to flourish because there were not enough primary care physicians to care for all of the people suddenly insured. ${ }^{2}$ And guess what? It's going to get worse. Currently, $32 \%$ of US physicians practice primary care. Over the last 3 years, the number of medical school graduates who will practice primary care is only $16 \%$, and federal programs that will reverse the trend have been eviscerated.

Here's an example: Since 2000, the funding for Federally Qualified Health Centers (FQHCs) has nearly doubled to almost $\$ 2$ billion. This is laudable. However, over the same time period, the funding for the programs that train the physicians most likely to practice in FQHCs (Title VII, Section 747) has been cut by $55 \%$. This is appalling. Ask Senator Evan Bayh of Indiana if the new Lucas Oil Stadium would have been built if Indianapolis didn't have a pipeline of loyal Colt fans or the promise of a pipeline of conventions. The pipeline of family physicians is running dry. 